\title{
Gender Differences in SCD Crises: Implications for Genetic Counselling and Psychotherapy
}

\author{
Oluwatoyin Olatundun Ilesanmi
}

\begin{abstract}
Painless and painful crises are common phenomena in sickle cell crises. People with sickle cell disorder(SCD) do experience both chronic and acute pain throughout life. The painful crisis is unpleasant with wide variation in intensity, quality, duration and persistence. It accounts for over $60 \%$ of hospital admissions in any given year of persons affected with SCD. Little attempt has been made to survey gender differences in frequency and intensity of pain as well as types of crises often experience by individuals suffering SCD. Thus researches focusing on gender differences in SCD crises are rare despite the fact that women often report lower pain thresholds, higher pain ratings, and lower to learned for pain. Men affected by SCD also experience low nitric oxide. Psychologically, women experienced high level of anxiety over pregnancy related crises. Thus, limited understanding and awareness exists among mental health practitioners on the need for genetic counseling and about the psychotherapeutic management of painful crises in persons affected by SCD. Hence, the need for this paper which attempt to examine the differences in crises as well as proffer solutions for the genetic and mental health implications of these disorders.
\end{abstract}

Index Terms-Counselling, genetics, psychotherapy, sickle cell disorders.

\section{INTRODUCTION}

Painless and painful crises are common phenomena in sickle cell disorder which is an inherited autosomal recessive genetic disorder of hemoglobin $(\mathrm{Hb})$ structure caused by point mutation at the sixth position in beta globin chain, valine substituting glutamic acid [1] The affected person inherits 2 mutant globin genes-one is always the sickle mutation (abnormal haemoglobin structure). This leads to periodic episodes of pain and damages the vital organs. Sickle red cells die after only about 10 to 20 days, instead of the usual 120 days. There are 4 important genotypes among patients of West African origin: SS, sickle cell-hemoglobin $\mathrm{C}(\mathrm{SC})$, sickle cell-beta thalassemia $\left(\mathrm{S} \beta^{\circ}\right.$ and $\left.\mathrm{S} \beta+\right)$. The most severe form of SCD is homozygous sickle cell anemia $(\mathrm{Hb}$ SS). Many affected persons do experience both chronic and acute pain throughout life. Painful crises are caused by recurrent acute vaso-occlusion usually occur whenever partially or totally deoxygenated Hgb molecules distort their normal disk shape, producing stiff, sticky, sickle-shaped cells that obstruct small blood vessels and produce vaso-occlusion as well as the disruption of oxygen to body tissues. Globally, Nigeria has the largest population of carriers / SCT - Hb AS; about 100,000 babies are born annually with SCA

SCD affects males and females equally, and is responsible for increased morbidity and mortality in affected persons. Significant gender differences in morbidity and mortality have been reported in adults with sickle cell disease [2]. For instance Garvin $\mathrm{Jr}$ [3] noted that morbidity appears to be increased in males. In a cooperative study of Sickle Cell Disease, Platt, et al [4] found the median age of death of 42 years for men and 48 years for women, a greater difference than in black control subjects. For example, hyper-hemolytic crisis is associated with red cell G6PD deficiency, and therefore considerably more likely in boys than girls. Garvin [5] also stated that gender related differences in red blood cell production are noted in adolescence and persist throughout adult life. Baum, Dunn, Maude, et al [6] also observed a striking increase in veno-occlusive crisis after age 15 years, with a greater rate of pain attacks in males than females. Gladwin, Schechter, Ognibene, et al [7] also found that female patients have slightly greater fetal hemoglobin levels, which may be protective; and concluded that the basis for these differences could lie in the observation that nitric oxide bioavailability and responsiveness are reduced in males but not females with sickle cell disease. The onset of puberty may be delayed by several years in both boys and girls with sickle cell disease.

In spite these findings little attempt has been made to survey gender differences in frequency and intensity of pain as well as types of crises often experience by individuals suffering SCD. Thus, limited understanding and awareness exists among mental health practitioners on the need for genetic counseling and about the psychotherapeutic management of painful crises in persons affected by SCD. Hence, this cross-sectional quantitative survey study was undertaken to assess the gender differences in sickle cell episodic painful crises among affected persons in Nigeria in order to proffer solutions for the genetic and mental health implications of sickle cell disorder.

\section{PURPOSE OF STUDY}

This cross-sectional quantitative survey study was undertaken to assess the gender differences in sickle cell episodic painful crises among affected persons in Nigeria in order to proffer solutions for the genetic and mental health implications of sickle cell disorder.

\section{RESEARCH QUESTIONS}

O. O. Ilesanmi was with Redeemer's University, RCCG Camp, Mowe, Ogun State, Nigeria. She is now with the Obafemi Awolowo University, Ile-Ife, Osun State, Nigeria (e-mail: ilesanmio@oauife.edu.ng, toytundun@aol.com).
- What are the demographical variables of the study's respondents? 
- How many of the male respondents have ever had painful erection without desire for sex?

- How many of the male respondents have experienced either a) stuttering or b) major priapism?

- How many of the respondents have ever been hospitalized for painful erectile crises?

- What are the physical changes experienced by the boys since age 12 ?

- Is there any increase in SCD crises which may be associated with these developmental tasks?

- How many of the female respondents menstruate?

- What are the ages of onset of menarche for those who do?

- Do the respondents ever experience severe SCD crises during menstruation?

- If yes, how often do they experience severe SCD crises during menstruation?

- How many of the respondents have ever been hospitalized for SCD crises during menstruation?

- What is the attitude of adolescent girls with sickle cell disease towards pregnancy?

- What are the reasons given for the negative feelings?

\section{Methodology}

The study adopted a cross-sectional quantitative survey research design. A total of 40 Male $=20,50 \% \&$ Female $=$ $20,50 \%$ respondents participated in the study. The face-to-face validated SCD Pubertal and Priapism Questionnaire was administered to them during their SCD club meetings in three different locations in Lagos States, Nigeria. The instrument consisted of three sections. Section A sought respondents demographical variables, Section B which is for Boys only sought information on priapism crises and onset of pubertal changes in adolescence, while Section C (- girls only) sought information on SCD crises in relation to Menstruation and general attitudes of respondents towards pregnancy. The instrument showed a modest degree of reliability coefficient of 0.78 using Guttman split-half paradigm, and a corresponding split-half internal consistency following Spearman-Brown where the reliability coefficient was 0.7862 . The Croncbach alpha of 0.80 reliability coefficient further exemplified a general measure of internal consistency. Percentages were calculated for statistical analysis using SPSS version 17.

\section{REsults}

Results obtained from this study indicated that 17(85\%) adolescent boys had experienced priapism (stuttering $=8$, $47 \%$ and major priapism $=9,53 \%)$; and that $12(71 \%)$ had been admitted at one point in time in the hospital for the treatment of priapism (see Table I-Table IV).

The findings of this study also showed that $80 \%$ of the female respondents had attained menarche; with the following variations their age of onset: 14 years $=3(18.75 \%)$; 15 years $=7(43.75 \%) ; 16$ years $=4(25 \%) ; \& 17$ years $=$ 2(12.5\%).

The findings also showed that $13(81 \%)$ of the girls who had attained menarche have had severe painful crises during menstruation and that $62 \%$ have experienced severe pains on monthly basis, $23 \%$ quite often and $15 \%$ once in a while. It also showed that $9(69 \%)$ of the girls had been hospitalized for SCD crises during menstrual flow in the past; and that 11 $(55 \%)$ of the girls had negative attitude towards pregnancy.

TABLE I: HB STATUS, EduCATIONAL BACKGROUND, AgE, RELIGION AND TRIBE OF RESPONDENTS BY SEX

\begin{tabular}{llll}
\hline \multirow{2}{*}{$\begin{array}{l}\text { Mb } \\
\text { Status }\end{array}$} & Hb SS & $17,85 \%$ & $15,75 \%$ \\
\cline { 2 - 4 } Educatio & Hb SC & $3,15 \%$ & $5,25 \%$ \\
\hline $\mathrm{n}$ & Primary & $3,15 \%$ & $4,20 \%$ \\
& Secondary & $10,50 \%$ & $11,55 \%$ \\
\multirow{2}{*}{ Age } & Tertiary & $7,35 \%$ & $5,25 \%$ \\
& 15 & $7,35 \%$ & $5,25 \%$ \\
& 16 & $4,20 \%$ & $6,30 \%$ \\
\multirow{2}{*}{ Religion } & Christian & $12,60 \%$ & $9,45 \%$ \\
& Muslims & $8,40 \%$ & $11,55 \%$ \\
Tribe & Hausa $=17.5 \%$ & $3,15 \%$ & $4,20 \%$ \\
& Igbo $=32.5 \%$ & $6,30 \%$ & $7,35 \%$ \\
& Yoruba $=50 \%$ & $11,55 \%$ & $9,45 \%$ \\
\hline \hline
\end{tabular}

\begin{tabular}{llll}
\multicolumn{4}{c}{ TABLE II: PARENTAL BACKGROUND BY SEX } \\
\hline \multirow{5}{*}{ Parental } & Civil servant & Male & Female \\
Occupation & self-employed & $4,20 \%$ & $6,30 \%$ \\
& unemployed & $6,30 \%$ & $9,45 \%$ \\
& single parent (Mother only or Father & $4,20 \%$ & $5,25 \%$ \\
& only) & $3,15 \%$ & $2,10 \%$ \\
\multirow{5}{*}{ Family } & Living with Both parents & $7,35 \%$ & $6,30 \%$ \\
& Divorced home & $4,20 \%$ & $3,15 \%$ \\
& Orphan & $1,5 \%$ & $2,10 \%$ \\
& Mother alive & $3,15 \%$ & $3,15 \%$ \\
& Father alive & $1,5 \%$ & $1,5 \%$ \\
\hline \hline
\end{tabular}

\begin{tabular}{lll}
\multicolumn{3}{c}{ TABLE III: MALE RESPONDENTS \& PRIAPISM } \\
\hline \multirow{2}{*}{$\begin{array}{l}\text { Experience with or } \\
\text { without priapism }\end{array}$} & \multicolumn{2}{c}{ Yes age = 15-18) } \\
\cline { 2 - 3 } & No & $3(15 \%)$ \\
\hline Types of priapism ever & stuttering & $8(47 \%)$ \\
experienced & major priapism & $9(53 \%)$ \\
Ever hospitalized for & Yes & $12(71 \%)$ \\
priapism & No & $5(29 \%)$ \\
physical changes from & Height (taller), Broadness of chest, Change in \\
Types of crises & voice & Bone pains, knee pains, pain in the arms, \\
& severe pains on the hip, leg pain, and malaria \\
\hline
\end{tabular}

\section{DISCUSSION}

The findings of this study on the gender differences in adolescents with SCD are similar to the observations of Gladwin et al in a study [8]. In a study conducted in Dallas with 21 African-American patients $($ men $=11 \&$ women $=10$, ages 18 to 55) with sickle cell disease and 18 African Americans without sickle cell disease (controls); Gladwin et al observed that Nitric Oxide (NO) is up to two times more available in women than men with sickle cell anemia [9]. The result showed that the men appear to have problems both in making nitric oxide and with increased destruction of nitric oxide. 


\section{IMPLICATIONS FOR GENETIC COUNSELLING AND PSYCHOTHERAPY}

The findings of this study have serious implications for genetic counseling and psychotherapy. The psychological complications in patients with SCD mainly result from the impact of pain and symptoms on their daily lives and society's attitudes towards them [10]. Both children and adults with sickle cell disease often suffer from depression. The financial costs of medical treatments combined with lost work can be very burdensome. Any chronic illness places stress on the patient and family, but sickle cell patients and caregivers often face great obstacles in finding psychological support for the disease. Anie et al. [11] have also shown that society's attitudes and perception do have a psychological impact on patients with SCD. Palermo et al. [12] also noted increased anxiety, depression, social withdrawal, aggression, poor relationships and poor school performance. Thus the impacts of its emotional strain from unpredictable bouts of pain, fear of death, and lost time and social isolation at school and work [13] are enormous. These are not just the physical pain which the patients endure, but emotional pain caused by psychological and social factors such as gender, age, education, and socioeconomic status. These thus set the imperatives for psychotherapists and genetic counselors to develop skills such as coping style, coping capacity, and social support that will assist affected persons deal with pain intensity, pain threshold, and pain tolerance, both clinically and in research settings. Thus, a thorough understanding of the key gender differences of vaso-occlussive crises among mental health practitioners will facilitate effective administration of genetic counseling and psychotherapy for the amelioration of psychosocial burden of these disorders. Thence, the need to provide answers to pertinent questions such as "what are the observable key gender differences in SCD crises? What are genetic counseling and psychotherapy? What types of genetic counseling and psychotherapy are needed for SCD patients and their care givers?"

TABLE IV: MENSTRUATING GIRLS (AGE $=15-18$ )

\begin{tabular}{|c|c|c|}
\hline \multirow{2}{*}{$\mathrm{N} \& \%$ of Menstruating girls } & Yes & $16(80 \%)$ \\
\hline & No & $4(20 \%)$ \\
\hline \multirow{4}{*}{ Age of menarche onset } & \multirow[t]{4}{*}{ Yes } & $14=(\mathrm{N}=3 ; 18.75 \%)$ \\
\hline & & $15=(\mathrm{N}=7 ; 43.75 \%)$ \\
\hline & & $16=(\mathrm{N}=4 ; 25 \%)$ \\
\hline & & $17=(\mathrm{N}=2 ; 12.5 \%)$ \\
\hline \multirow{2}{*}{ Experience severe SCD crises during menstruation } & Yes & $13(81 \%)$ \\
\hline & No & $3(19 \%)$ \\
\hline \multirow[t]{3}{*}{ Frequency of severe SCD crises during menstruation } & Monthly & $8(62 \%)$ \\
\hline & Quite often & $3(23 \%)$ \\
\hline & once in a while & $2(15 \%)$ \\
\hline \multirow[t]{2}{*}{ Ever hospitalized for SCD crises during menstruation } & Yes & $9(69 \%)$ \\
\hline & No & $4(41 \%)$ \\
\hline \multirow[t]{2}{*}{ Attitude Towards Pregnancy } & Positive & $9(45 \%)$ \\
\hline & Negative & $11(55 \%)$ \\
\hline Attitudes towards pregnancy & \multicolumn{2}{|c|}{$\begin{array}{l}\text { Going through pregnancy and labour procedure might be like adding pain to pain; I am } \\
\text { indifferent though the idea of getting pregnant is scary; I am not sure I can combine the } \\
\text { stress to the SCD crises; I am afraid; the pregnancy crises might be worse than what I } \\
\text { am currently experiencing during menstruation; Pregnancy may worsen the frequency } \\
\text { of crises and degree of excruciating pain that I experience monthly; I am scared, } \\
\text { because I know someone who died of pregnancy complications; I do not want to } \\
\text { imagine the painful crises it may cause, I just want to live one day at a time; I do not } \\
\text { know which SCD crises I will survive; }\end{array}$} \\
\hline
\end{tabular}

\section{KEY GENDER DIFFERENCES IN SCD CRISES}

A thorough review of literature has revealed the following gender difference in VOC: -Inflammation in the arteries (sickle cell disorders have been linked to inflammation in the arteries, probably due to the blocking of the blood vessel by the misshapen red blood cells); Low level of Nitric Oxide in males; Acute and Chronic Complications more likely in boys than girls; Morbidity and Mortality (Platt, et al., reported a median age of death of 42 years for men and 48 years for women, a greater difference than in black control subjects in a study) [14]; onset of pubescence (This may be delayed by several years in both boys and girls with sickle cell disease); and Menstruation \& PMS (These could be traumatizing for girls with HbSS, SC \& SBeta $^{+-}$Some girls have reported an increase in episodes of painful crisis during their menstrual periods because they are losing blood on top of their low hemoglobin count); Others include priapism and pregnancy related crises.
Priapism is an unwanted, prolonged erection of the penis in males with $\mathrm{Hb} \mathrm{SS}, \mathrm{SC}, \mathrm{S}-\beta$ thal etc. It can last for hours and often causes pain. it often occurs during sleep. Priapism does not occur because of sexual feelings or desires. Rather it occurs when red blood cells sickle and change the chemistry of the blood, causing a blockage of normal blood flow draining from the penis. There are two major types of priapism- a) Come and Go form which is also known as stuttering priapism and b) Stay for Long type which is also known as Acute or Major priapism. Major priapism is often preceded by a long history of minor or stuttering episodes. In a prevalence study conducted by Adeyoju et al. [15] on a sample of 130 males with SCD in UK \& Nigeria with Mean age $25 \mathrm{y}$ SD 11 ; range $4 \mathrm{y}-66 \mathrm{y} ; 78 \% \mathrm{SS} ; 15 \% \mathrm{SC} ; 1.5 \%$ S-thal; 46 (35\%) reported history of priapism; 72\% stuttering $\& 52 \%$ major priapism; Mean age of onset was $15 \mathrm{y} ; 75 \%$ first episode before age 20y; and of $46(35 \%)$ with priapism 10 $(21 \%)$ reported erectile dysfunction. Pregnancy related complication include high-risk pregnancies mainly because 
of fetal risks; infections and thromboembolic events); cesarean deliveries; gallbladder problems; acute Sequestration Crisis; preeclampsia, eclampsia, preterm labor/birth, placental abruption, fetal growth restriction, miscarriage $(0-30 \%)$, a low-birth-weight baby i.e. $<2.5 \mathrm{~kg}$; Stillbirth or Intra-Uterine Growth Restriction (malnutrition)affecting baby.

\section{The Treatment Modalities}

VOC require multidisciplinary care from sickle cell specialist such as psychologists, genetic counsellors, paediatricians, physicians, haematologists, obstetricians, orthopaedic surgeons, urologists and nurses. The training, dedication and experience of above members of the team can make a significant difference to quality of lives and survival.

\section{Genetic Counseling AND PSYCHOTHERAPY}

Genetic counseling is one of the fundamental means of reducing the impact of or eliminating sickle cell disorder. It enables parents and affected individuals to make informed decisions in their own interest about future family planning on pregnancies. In developing Nations like Nigeria, there is a dearth of qualified genetic professionals and genetic services are rare and are rarely consulted except when there are manifest problems. The view available ones are seldom consulted except in cases of severe or chronic deliberating problems. It is therefore, imperative for genetic counseling to be encouraged in Nigeria for genotype testing before marriage; prenatal diagnosis and informed decision on whether to keep or terminate affected pregnancy when one or both parents are positive; before the adolescent becomes sexually active and should be reinforced periodically. Available genetic counseling services which could be offered persons with SCD and their care givers are preconception Counseling (PC); Pregnancy and Abortion Counselling; Genetic Screening; Antenatal Haemoglobinopathy Screening; Multiple Pregnancies and safe delivery and Spousal selection counseling.

\section{What Is The REALITY OF IMPLEMENTING GENETIC COUNSELLING AND PSYCHOTHERAPY IN NIGERIA?}

First, the religious specificity and cultural sensitivity of the Nigerian society to marriage, singleness, and childlessness are likely to hinder a lot of Nigerians from accessing genetic counseling services such as genotype diagnosis before marriage, pre-conception counselling and pre-natal diagnosis.

Also, the socio-economic factors (e.g. poverty, work in the family) are closely related to health and negatively impact SCD affected persons in Nigeria. In terms of health care financing, the adverse effects of poverty on the health of SCD affected persons are well established in literature [16]. It is also reflected in their access to modern diagnostic equipment and health services [17]. Individually financed health services leave large groups of the affected population, especially those from the lower economic groups without coverage. There are high rate of poverty (50-60\%) among affected families, particularly those in the rural areas [18]. Majority of them cannot afford maintenance of routine medication and drug compliance; neither could they afford genetic counseling and psychotherapeutic services. This therefore necessitates the need for a holistic integration of genetic counseling services and mental health care at PHC level across the nation.

\section{RECOMMENDATION}

First is the need for creation of large scale awareness the nation about the importance of genetic services. Although, presently, no genetic counseling clinic is known [19] in Nigeria. Large scale awareness of genetic understanding and screening is yet to be implemented in Nigeria [20]. Genetic counseling and the diagnosis are usually made in general practice when it is presented with a severe complication. Even when tragedies such as two or more miscarriages, still births, or children die in infancy, many at times doctors do not order a blood test to take a closer look at genetic make-up of parents or refer them to a genetic counselor. Therefore, the most important challenge is to raise the awareness on its causes and prevention through health education [21]. Hence the need for greater awareness about sickle cell disorders, especially in sub-Saharan African and Nigeria in particular.

There is also the need for Advocacy engagement with policy makers and key stakeholders on health matters in the Society. The economic, social and psychological impact of sickle cell disorders on patients are often neglected in rural communities in Nigeria. Therefore, Nigerian Government need to integrate genetic counseling and mental health into primary health care, provide mental health care in general hospitals and develop community-based mental health services. This is because primary Health Care (PHC) service is the first level of health care that most people encounter and feel comfortable with at the grassroots.

Next is the need for training and curriculum review. In view of the urgent needs for these services in Nigeria, it is apt for key stakeholders in the education industry and curriculum developers to mainstreaming genetic counseling and psychotherapy training into core clinical psychology training in tertiary institutions across the nation. This will build capacities of trainees in becoming well-informed genetic counselors and psychotherapists. There is also the need for development of therapy manuals and practice guidelines in for effective implementation in biopsychosocial management of SCD which may include brief therapy, individual therapy and group therapy techniques. The key stakeholders are administrators responsible for developing and approving psychotherapy training programs which includes psychotherapists in universities and members of curriculum committees; teachers and supervisors who directly provide psychotherapy training; and the consumers; that is, those who receive psychotherapy training and provide psychotherapy to patients [22].

Finally, the is the need for public education on the basics of genetic counseling across the nation. Bankowski and Capron [23] suggested that education about human reproduction and genetics should be part of the educational 
heritage of every person. The principle of respect for persons and the "ethics of care" suggest that individuals and families should participate in decision making [24]. Generally, users of genetic services are more likely to assess information accurately, more likely to reach informed decisions, and more likely to cooperate in treatment if they work together actively with professionals. In order for individuals and families in Nigeria to be active participants, it is necessary that they receive some basic education about genetics. This can best be achieved for the public through education in schools, education of the media and education of health workers in contact with individuals at the primary health care level. Combining educational goals with community genetic services and prevention measures integrated into primary health care may prove very valuable in disseminating the correct genetic information to the population in general [24].

\section{CONCLUSION}

The societal burden of SCD is genetically mediated and sometimes complicated by economic and environmental factors, thus, requiring multi-disciplinary care, most especially the contributions of behavior geneticists and other mental health practitioners for the psychosocial management of any form of psychopathological condition traceable to behavior deficits and conflicts over repressed childhood traumas and SCD associated pains.

\section{APPENDIX}

\section{SCD Pubertal and Priapism Questionnaire}

\section{Oluwatoyin Olatundun ILESANMI (PhD)}

This questionnaire is designed solely for research purposes. Any information provided will be used strictly for academic exercise only. The instrument is purely seeking information on the relationship between SCD crises and adolescents developmental tasks, particularly the experience of menarche and menstruation in girls and pubertal changes in boys with $\mathrm{SCD}$. Your cooperation in filling the questionnaire is therefore highly requested. Thank you.

Section A: Biographical Variables

1) Sex: Male Female

2) Age: $\begin{array}{llll}15 & 16 & 17 & 18\end{array}$

3) Blood Group: $\mathrm{O}^{+} \mathrm{O}^{-}$

4) Hb: $\mathrm{SS} \mathrm{SC} \mathrm{SD} \mathrm{SO}^{+} \mathrm{SO}^{-}$

5) Educational Status: Primary only Secondary Tertiary

\section{6) Parental Background:}

- What kind of home are you from? Single parent (Mother only or Father only); Both parents; Divorced home; Orphan; Mother alive; or Father alive

- Parental Occupation: Artisan; Civil servant; self-employed; unemployed

- Sibblings: only child; or number of sibblings:---

Section B: Boys Only

1) Have you ever had painful erection without desire for sex? Yes or No

2) If yes, how was the experience? Is it: a) come and go or b) stay for long?
3) Have you ever been hospitalized for painful erectile crises?

4) Since age 12, do you notice any changes in your physical growth? Yes or No

5) If yes, what are the physical changes?

6) Has there been any increase in your SCD crises which may be associated with these physical changes?

Section C: Girls only

1) Do you menstruate? Yes or No

2) If yes, at what age did you see your first menstrual flow?

3) Have you ever experienced severe SCD crises during menstruation? Yes or No

4) If yes, how often? Monthly Quite often Once in a while

5) Have you ever been hospitalized for SCD crises during menstruation? Yes or No

6) What is the attitude of adolescent girls with sickle cell disease towards pregnancy? Positive or Negative

7) If negative, why?

\section{ACKNOWLEDGMENT}

The author is not indebted to anyone in the course of this research. This was a self-sponsored research.

\section{REFERENCES}

[1] P. Deshmukh et al., "Prevalence of Sickle Cell Disorders in Rural Wardha," Indian Journal of Community Medicine, vol. 31, no. 1, pp. 26-27, 2006.

[2] M. Kamble and P. Chaturvedi, "Epidemiology of sickle cell disease in a rural hospital of central India," Indian Pediatrics, 2000, vol. 37, no. 391-396.

[3] J. H. Garvin, Jr, "Gender-Specific Aspects of Pediatric Hematology and Oncology," in M. J. Legato Ed., Principles of Gender-Specific Medicine, 2nd ed., Elsevier: Academic Press, 2009, pp. 52-53.

[4] O. S. Platt, D. J. Brambilla, W. F. Rosse et al., "Mortality in sickle cell disease, Life expectancy and risk factors for early death," $N$ Engl J Med., 1994, vol. 330, no. 23, pp. 1639-1644.

[5] J. H. Garvin, Jr, "Gender-Specific Aspects of Pediatric Hematology and Oncology," in M. J. Legato Ed., Principles of Gender-Specific Medicine, 2nd ed., Elsevier: Academic Press, 2009, pp. 52-53.

[6] K. F. Baum, D. T. Dunn, G. H. Maude et al., "The painful crisis of homozygous sickle cell disease: a study of the risk factors," Arch Intern Med., 1987, vol. 147, pp. 1231-1234.

[7] M. T. Gladwin, A. N. Schechter, F. P. Ognibene et al., "Divergent nitric oxide bioavailability in men and women with sickle cell disease," Circulation, 2003, vol. 107, pp. 271-278.

[8] M. T. Gladwin, A. N. Schechter, F. P. Ognibene et al., "Divergent nitric oxide bioavailability in men and women with sickle cell disease," Circulation, 2003, vol. 107, pp. 271-278.

[9] K. A. Anie, "Psychological complications in sickle cell disease," British Journal of Haematology, vol. 129, pp. 723-729, 2005.

[10] K. A. Anie, "Psychological complications in sickle cell disease," British Journal of Haematology, vol. 129, 2005.

[11] K. A. Anie, "Psychological complications in sickle cell disease," British Journal of Haematology, vol. 129, pp.732. 2005.

[12] T. M. Palermo, L. Schwartz, D. Drotar, and K. Mcgowan, "Parental report of health-related quality of life in children with sickle cell disease," Journal of Behavioral Medicine, vol. 25, pp. 269-83, 2002.

[13] O. A. Barbarin, C. F. Whitten, and S. M. Bonds, "Estimating rates of psychosocial problems in urban and poor children with sickle cell anemia," Health and Social Work, vol. 19, pp. 112-9, 1994.

[14] O. S. Platt, D. J. Brambilla, W. F. Rosse et al., "Mortality in sickle cell disease, Life expectancy and risk factors for early death," $N$ Engl $J$ Med., 1994, vol. 330, no. 23, pp. 1639-1644, 1994.

[15] A. B. Adeyoju, A. B. K. Olujohungbe, J. M. Ris, A. Yardumian, D. Bareford, A. Akenova, O. Akinyanju, K. Cinkota, and P. H. O'Reilly, "Priapism in sickle-cell disease; incidence, risk factors and complications - an international multicentre study," BJU International, vol. 90, pp. 898-902, 2002.

[16] M. M. Alsan, M. Westerhaus, M. Herce, K. Nakashima, and P. E. Farmer, "Poverty, global health, and infectious disease: lessons from 
Haiti and Rwanda," Infect Dis Clin North Am, vol. 25, no. 3, pp. 611-22, 2011.

[17] O. Akinyanju, "Issues in the Management and Control of Sickle Cell Disorder," Archives of Ibadan Medicine, 2001, vol. 2, no. 2, pp. 37-41.

[18] M. M. Alsan, M. Westerhaus, M. Herce, K. Nakashima, and P. E. Farmer, "Poverty, global health, and infectious disease: lessons from Haiti and Rwanda," Infect Dis Clin North Am, vol. 25, no. 3, pp. 611-22, 2011.

[19] O. A, Adeyemo, O. O. Omidiji, and O. A. Shabi, "Level of awareness of genetic counselling in Lagos, Nigeria: its advocacy on the inheritance of sickle cell disease," African Journal of Biotechnology, vol. 6, no. 24, pp. 2758-2765, 17 December, 2007.

[20] O. Akinyanju, "Issues in the Management and Control of Sickle Cell Disorder," Archives of Ibadan Medicine, 2001.

[21] O. A, Adeyemo, O. O. Omidiji, and O. A. Shabi, "Level of awareness of genetic counselling in Lagos, Nigeria: its advocacy on the inheritance of sickle cell disease," African Journal of Biotechnology, vol. 6, no. 22, pp. 2758-2766, 17 December, 2007.

[22] O. O. Ilesanmi. (2012). Genetic Counselling and Logotherapy: Implications for Psychotherapists Interested in Genetic Disorders. Global Journal of Human Social Sci. [Online]. 12(2). Available: http://socialscienceresearch.org/index.php/GJHSS/article/view/276
[23] Z. Bankowski and A. M. Capron, "Genetics, Ethics and Human Values: Human Genome Mapping, Genetic Screening and Gene Therapy," in Proc. XXIVth CIOMS Conference, Tokyo and Inuyama City, Japan, 22-27 July 1990, CIOMS, Geneva, Report of the Working Groups, 1991, pp. 178-190.

[24] D. C. Wertz, J. C. Fletcher, and K. Berg, "Review of Ethical Issues in Medical Genetics Report of Consultants to WHO,” 2003.

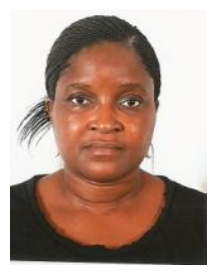

Oluwatoyin O. Ilesanmi is a Nigerian. She studied clinical psychology (PhD/June, 2005) and Guidance \& Counselling (MEd/1999) at the University of Ibadan, Nigeria. She obtained a Bachelor's of Arts Degree in English Studies (1987) from University of Ife, Nigeria. She obtained further professional training in Dispute and Conflict Analysis (2007), Gender Perspectives in United Nations Peacekeeping Operations (2009), Civil-Military Coordination (CIMIC) (2009), and Global Terrorism (2009) under Peace Operations Training Institute. She is a trained genetic counsellor (2009) under Sickle foundation, Nigeria; and a member of the Nigerian professional negotiator and mediator. 